Published in Philosophy of History: Twenty-First-Century Perspectives, ed. Jouni-Matti

Kuukkanen (London: Bloomsbury, 2020), 165-179. Chapter DOI:

$10.5040 / 9781350111875.0016$

History and Philosophy of History (HPH): A Call for Cooperation

Herman Paul

\title{
Introduction
}

In a recent article, the philosopher Jutta Schickore laments what she perceives as a widening gap between philosophers of science, on the one hand, and historians of science, on the other. Although historians and philosophers of science sometimes work together in programs labelled 'HPS' - history and philosophy of science - their cooperation is increasingly frustrated, or so Schickore believes, by historians of science. Under influence of a 'cultural turn' in the humanities and social sciences, these historians are exchanging their traditional subject matter - scientific concepts and theories in their historical development - for a much broader variety of themes, varying from laboratory practices and cultures of note-taking to scientific masculinities and geographies of science. In Schickore's words:

[T] oday, historians of science are interested in the usage in education and circulation of diagrams; the streets, shops, back alleys, and gardens, the merchants, gardeners, barber-surgeons, midwives, engineers, and alchemists of Elizabethan London who set the stage for the Scientific Revolution; or the role of commerce for scientific exchanges in the early modern period. Such interests are of course legitimate and important for history of science, but these orientations make it harder for philosophers to find relevant 'test cases' [for their philosophical projects] (Schickore 2011: 465-6).

What kind of implications, one might wonder, does the cultural turn among historians of science have for the cooperation institutionalized as HPS? Will HPS come to an end, with historians and philosophers drifting away from each other? Does HPS need to be reinvented, for instance as 'integrated HPS' (Arabatzis and Schickore 2012; Scholl and Räz 2016; Stadler 
2017)? Or can philosophers do without historians of science, for instance by writing their own histories of scientific theories (Schickore 2018: 196)?

To a considerable extent, Schickore's observations about historians moving away from traditional philosophical themes also apply to historians of historiography. In a not-too-distant past, historical and philosophical reflection on historical studies used to go hand in hand. The Commission of the History of Historiography, for instance, was founded in 1980 under auspices of the International Committee of Historical Sciences to shed historical light on the theoretical and methodological quarrels that divided historians at the time (Erdmann 2005: 278-98). ${ }^{1}$ Likewise, history and philosophy of history were close to inseparable in what Western European historians called Historik (historics) or theoretische geschiedenis (theoretical history) (Otto 1998). Such cooperation is no longer self-evident, though. Recent work in the history of historiography tends to focus on cultural-historical themes like the gendered aspects of historians' work (Schnicke 2015; Porciani 2009; Smith 1998), the habits and routines of historians working in archives (Müller 2019; Trüper 2014; Saxer 2013; Wimmer 2012), or the commemorative practices in which historians engage (Paul 2017; Creyghton 2016; Tollebeek 2015). This not only reveals an interest in other themes than explanation, narrative, or representation, but also a methodological orientation on other fields than philosophy. Jo Tollebeek (2008), most notably, calls for an 'anthropology of modern historical scholarship', characterized by thick description instead of conceptual analysis. (Arguably, historians of historiography are not alone responsible for this growing distance: philosophers of history also contribute their share. When in 2007 the Journal of the Philosophy of History was founded with the aim of fostering dialogue between philosophers of history and analytical philosophers of language, historians of historiography were not mentioned at all [Ankersmit et al. 2007].) This lends some urgency to the question as to how historians and philosophers of history relate to each other: will they continue to drift apart?

In this chapter I will argue that a parting of their ways is detrimental to the project of understanding historical studies, that is, understanding what historians do when they study the past. Such a project requires historical sensitivity (which historians of historiography can bring to the table) as well conceptual clarity (which philosophers of history are able to offer). Arguing in favor of historical-philosophical cooperation is not the same, though, as trying to revitalize Historik or theoretische geschiedenis. While these genres focused near exclusively on historians' concepts, ideas, and ideologies, the approach defended in this chapter is much 
broader: it wants to do justice to the entire variety of practices, discourses, materialities, and emotions that make up historical studies. I will therefore propose a new term and argue in favor of ' $\mathrm{HPH}$ - a historical equivalent of HPS called history and philosophy of history. Obviously, I do so in full awareness of the problems that have surrounded HPS, including especially the false expectations raised by that label. So I will start with some brief comments on HPS - what it is and what it is not. Subsequently, I will present four arguments in favor of $\mathrm{HPH}$. Finally, I will respond to some questions that my proposal might provoke, suggesting among other things that HPH is not something to be built from scratch, but a form of cooperation that is already among us, whether we call it by that name or not.

\section{History and philosophy of science}

What is HPS? When Ronald Giere (1973) described the history and philosophy of science as a 'marriage of convenience' rather than an intimate love relationship, he introduced a metaphor with which historians and philosophers of science have been playing ever since (McMullin 1976; Burian 1977; Krüger 1979; Domski and Dickson 2010: 1-3). ${ }^{2}$ Surely, there were signs of attraction, perhaps even love, between historians and philosophers of science in the 1960s. By the 1970s, conferences, book series, and educational programs, all carrying HPS in their titles or names, suggested that flirting and dating had turned into a serious relationship (Schickore 2011; Gooday 2006). Both partners seemed convinced that understanding science required combination, perhaps even integration, of conceptual and empirical perspectives. Yet the question nagged: Did the partners really love each other or was their 'marriage for the sake of reason' mainly grounded in a negative desire to leave the parental home? Sharing a flat named HPS, said Giere (1973: 283), 'may be better than living with one's parents, history and philosophy respectively ... But does it have the passionate involvement and deep communication that one was led to expect?'

Analyzing 'the marriage, relationship prospects, and level of intimacy' of HPS in the 1960s and 1970s, Schickore (2011: 455) observes that especially philosophers in the 1970s engaged in intensive 'marriage counselling.' Ironically, however, their diagnoses and advises were so divergent as to call the entire marriage metaphor into question. Historians and philosophers engaged in HPS were too diverse in terms of their agendas, projects, and expectations to fit the image of a romantic couple. In Schickore's grimmer imagery, the HPS arena rather 'was one of several battlefields' (2011: 455). On top of that, the marriage 
metaphor obscured that HPS not only enabled philosophers and historians to meet each other. From the very beginning, there was also science itself - which led Lorenz Krüger (1979: 112) to propose a marriage à trois - as well as 'sociology of scientific knowledge' (SSK) and 'science and technology studies' (STS), nephews who maintained difficult relationships with HPS (Riesch 2014).

In retrospective, the marriage metaphor seems to have done HPS little good. It was too romantic an image, if only because it raised expectations ('a union of souls', marital fidelity) that were quite inappropriate for what was, after all, nothing but a cautious attempt at interdisciplinary exchange and cooperation. Would it have been more appropriate to characterize HPS as a 'trading zone' or 'contact zone'? Surely these terms, borrowed from Peter Galison (1997, 2010), are more to the point. They emphasize contact, communication, and exchange across disciplinary divides without imposing an ideal, romantic or otherwise, of how such exchange ought to look like. At the same time, 'trading zone' and 'contact zone' are rather general terms: they don't convey that historians and philosophers of science engage in joint activities with the specific purpose of learning from each other 'how science works' (Giere 2012: 61).

Let me therefore propose an alternative label, freely borrowed from philosophers in the Gadamerian tradition. I would like to think of HPS as a hermeneutic space: a realm where scholars encounter, try out, appropriate, reject, or otherwise engage with ideas, concepts, methodologies, and practices from outside of their own fields (Figal 2010). As the adjective 'hermeneutic' conveys, the purpose of this exchange is not to reach common ground or to institutionalize cooperation, but to facilitate learning processes that hopefully yield new ideas and fresh approaches. As with workshop sessions and conference panels, or spontaneous chats with colleagues at the coffee machine, the outcome of such exchanges can never be predicted. However, within these limitations, conditions favorable to mutual learning can be created. If historians and philosophers of science spend time together, trying to understand each other's questions, listening to each other's arguments, opening themselves up to unfamiliar idioms or practices, analyzing case studies from a variety of conceptual perspectives, trying to translate historians' ideas into philosophical language and vice versa, subjecting grand claims to critical scrutiny, and testing conceptual distinctions against empirical examples, there is a fair chance that their understanding of 'how science works' will be deepened. So, by calling HPS a hermeneutic space, I seek to draw attention, not to 
institutionalized modes of transdisciplinary cooperation, but to what I regard as the heart of the matter: patient exchanges between historians and philosophers of science who believe that, in some way or another, they can learn from each other. As Scott Weingart (2015: 202) helpfully puts it: 'The question should not be whether history of science and philosophy of science can be fully integrated, but to what extent each can contribute to the other, and whether interesting results can come of studies pulling ideas and methodologies from both.'

\section{Why HPH?}

To what extent would a historiographical equivalent of HPS so conceived of be desirable? What would be the benefits of philosophers of history, historical theorists, historians of historiography, and historians of historical culture engaging in history and philosophy of history (HPH)? Three or perhaps even four arguments in favor of such exchange can be given. There is, in the first place, a broadly felt (though never uncontested) need to naturalize philosophy of history. Just as philosophy of science in the wake of Thomas S. Kuhn and W. V. O. Quine has gradually exchanged the normative question as to how science should look like for the empirical question how science actually looks like (Zammito 2004), philosophy of history is often believed to benefit from taking a naturalizing approach to the study of history (Bevir and Paul 2012). Concretely, this means that interpretations, explanations, inferences, narratives, and so forth should not primarily be studied conceptually, in order to identify the ideal features of a historical interpretation, explanation, inference, or narrative, but empirically, with an eye to uncovering what kinds of interpretations, explanations, inferences, and narratives historians (and others) actually produce or consume.

One of the most outspoken advocates of such a naturalized philosophy of history is Raymond Martin, whose 1989 book The Past Within Us was one long plea for an 'empirical approach to philosophy of history.' Observing that philosophers of history had been 'primarily concerned with what is possible in principle, rather than with what is actual or with what is possible in fact' (1989: 5), Martin urged his colleagues to redirect their attention to 'an examination of facts, the most central of which are the ways historians argue that one interpretation is better than its competitors' (1989: 6). Accompanying articles in History and Theory illustrated the kind of research that Martin had in mind: detailed analysis of how historians evaluate the merits of competing historical interpretations and measure 'progress' in their fields of study (Martin 1997, 1998). 
In paying close attention to historians' work, Martin followed a model laid out by William Dray (1964: 41-58) and Alan Donagan (1969, 1970), well before 'naturalizing' became a household term among philosophers of science. Martin's example, in turn, has been taken up by Chris Lorenz and Martin Bunzl, among others. ${ }^{3}$ Both argue that philosophers of history have the task of elucidating historians' practice by analyzing how this practice actually looks like. If historians turn out to spend much energy debating the relative plausibility of their historical accounts, philosophers of history have to make sure they can account for such debates - which Lorenz (1994) and Bunzl (1997: 3, 14, 23, 107) believe that only some philosophical approaches are capable of doing. So here we have a first raison d'être for HPH: philosophy of history should be able to offer insight into real-existing historical studies.

Closely related is a second motive behind both HPS and HPH: a desire to subject philosophical claims about scientific (historical) practice to empirical scrutiny. As illustrated by Larry and Rachel Laudan's so-called VPI project on scientific change, ${ }^{4}$ empirical testing of philosophical theories is an enterprise fraught with difficulty, if only because the data selected to this end are always theory-laden (McAllister 2018; Dumouchel 1991; cf. Donovan, Laudan, and Laudan 1992). Yet despite the project's flaws, the basic intuition behind it was correct, or so I would argue. Philosophers of science cannot make empirical claims about scientific practice without offering empirical support for these claims. So, if they assert, as Thomas Kuhn once did, that 'new assumptions are introduced, and initially accepted, chiefly by scientists who are either young or new to the field' (Kuhn 1970: 90, 151-2, as paraphrased in Laudan et al. 1986: 186), they have the burden of proof to demonstrate that there is an actual correlation between scientists' willingness to accept new theories and their degree of academic socialization. Likewise, if philosophers of history argue that historians 'seldom explicitly formulate general causal theories' (Dray 1989: 56), generally 'agree on theories and evidence' (Tucker 2004: 142), 'in seeking to explain their own discipline, do not characteristically use historiography to do it' (Gorman 2008: 9), and typically strive 'to achieve the 'history narrator as nobody' effect' (Jenkins 2003: 11), they put forward empirical claims that, as such, must be able to stand up to empirical testing.

Bunzl and Lorenz engage in such theory testing when they subject some of Arthur Danto's and Frank Ankersmit's work to empirical scrutiny. In response to Danto's assumption that all historians write narratives, Bunzl (1997: 32-3) points out that narrative modes of representation are not equally important in all historical genres: cross-cultural and cross- 
temporal studies like Natalie Zemon Davis 1978 study of male-female festive role inversions in cultures across the globe badly fit Danto's model. Likewise, Lorenz takes issue with Ankersmit's thesis that historical representations can only be evaluated on aesthetic grounds. Judging by, for instance, the German Historikerstreit, historians evaluate competing accounts of the past on epistemic grounds, too (Lorenz 1994: 314). Although it is questionable to what extent this falsifies Ankersmit's thesis, the case does raise important questions. How representative, for instance, is the Historikerstreit for historians' debating conventions? Is it true, as Ankersmit suggests, that historians debate epistemic issues only at statement level? And in case the answers to these questions vary across the spectrum of historical studies, is it true that philosophers of history often draw their examples from specific types of historical studies (Ankersmit 2001: 262), which implies - given the heterogeneity of historical practice - that their empirical claims tend to have local rather than universal validity (Bunzl 1997: 23)? These are issues of the sort that HPH is well-positioned to examine.

On top of that, HPH offers historians conceptual tools for reflection on their own practice. ${ }^{5}$ Varying on Laudan's argument that philosophers' conceptual distinctions may help historians develop more finely textured understandings of the history of science (Laudan 1989: 10), one might argue that historians' understanding of the 'causes' of $A$, the 'intentions' of $B$, or the 'influences' of $C$ might benefit from explicit reflection on what the concepts of 'causality', 'intention', and 'influence' entail. In a classic article on concepts of causation in historical studies on the origins of World War II, William Dray illustrated this point by showing that A. J. P. Taylor and his critics, including especially Hugh Trevor-Roper, spilled much ink debating whether Adolf Hitler 'intended the war', but never specified what they understood 'intended' and 'the war' to mean - thereby leaving it 'extraordinary obscure exactly what [was] being debated' (Dray 1978: 155). Likewise, Dray pointed out that the controversy evoked by Taylor's thesis about Hitler's foreign policy being not unusual for European government leaders in the 1930s might have been much more productive if Taylor and his critics had tried to clarify their 'standards of normality' and the implicit comparisons on which these standards were based (Dray 1978: 162). By identifying shared assumptions behind disagreements as well as by classifying different ways in which historians used terms like 'cause' and 'intention', Dray thus offered philosophical assistance to historians debating the merits of Taylor's work, in the hope of helping them avoid talking at cross-purposes. ${ }^{6}$ 


\section{Why HPH? (Cont'd)}

The three arguments in favor of $\mathrm{HPH}$ that I have offered so far are obviously related, not merely because the project of increasing the level of conceptual reflectivity among historians (no. 3) will surely fail without proper attention to historians' actual work (no. 1), but also because they are all inspired by HPS. Indeed, all authors cited so far are interested in the 'scientific' aspirations of academic historical studies and, consequently, try to analyze historians' work analogous to how philosophers of science scrutinize science. Yet there is no reason why HPH should focus exclusively on what I have elsewhere called historians' 'epistemic relations' with their pasts - that is, on engagements with the past that aim for epistemic goods like knowledge and understanding. If philosophers of history want to understand historical studies (concern no. 1), test philosophical theories (no. 2), or help historians reflect on what they are doing (no. 3), among the first things they should realize is that historians always maintain multiple relations with their subject matter, including aesthetic, moral, and political ones (Paul 2015a/b). ${ }^{7}$ These aesthetic, moral, and political dimensions of historical studies, in turn, can be subjected to similar analysis as the epistemic aspect on which the authors mentioned so far have focused their attention. Indeed, they should be studied with similar vigor if philosophers of history have the ambition of understanding historical studies as they actually exist.

This is to say that philosophers of history, in addition to continuing work on classic epistemic themes, might want to subject aesthetic, moral, and political aspects of historical studies to more rigorous philosophical study than these subjects have received so far. For although the so-called narrativist turn in philosophy of history, half a century ago, has produced important insights into the aesthetic, moral, and political aspects of historical writing, the question as to how this writing emerges out of historical studies - historians' habits of reading, note-taking, thinking, corresponding, collaborating, teaching, supervising, and reviewing (not to mention writing grant applications) - has hardly been addressed so far. Consequently, when it comes to aesthetics, morality, and politics, studies in philosophy of history - perhaps with the exception of Frank Ankersmit's Sublime Historical Experience (2015) - usually have little to say about these themes except insofar as they show up in historical writing. To be best of my knowledge, a philosophy of historians' research ethics has not yet been developed. A philosophy of 'feelings rules' in historical studies - it is allowed to weep over the execution of the Dutch grand pensionary Johan van Oldenbarnevelt, as a Dutch 
historian reportedly did in his lecture course on seventeenth-century history (Van der Meiden 1982)? - does not yet exist. And why does philosophy of history persist in studying historical studies through the prism of individual historians, while collaboration in various forms is increasingly becoming the standard in our age of grand-scale research projects?

From this it follows that the 'cultural turn' that philosophers of science committed to HPS perceive as a threat to the project of confronting philosophical theories with historical evidence may actually turn out not to be a threat at all (Pinnick and Gale 2000; Schickore 2011: 465-6). ${ }^{8}$ While it is true that the cultural turn has inspired historians of science to explore themes that are rather far removed from philosophy of science's traditional subject matter think of recent work on geographies of science (Livingstone 2003; Nayler 2005), moral economies (Daston 1995), scientific personae (Daston and Sibum 2003), and scientists' emotions (Dror 2006; White 2009) - philosophers of science might take this as an invitation to reflect philosophically on these still understudied aspects of science. ${ }^{9}$ Likewise, philosophers of history might benefit from a cultural turn in the history of historiography. Although studies on historians' working manners, social codes, commemorative practices, and gendered self-images examine aspects of historical studies quite different from the interpretations, explanations, inferences, and narratives that have dominated philosophy of history in the past half a century, precisely for this reason they might serve as welcome provocations. Philosophers of history might want to explore whether and how these themes fit their theories of historical studies - and what needs to be done in case they fit badly.

Arguably, historical research can even put new items on the philosophical agenda. Recent historical studies on historians' virtues and vices, for instance - the kind of work in which I am currently involved - raises questions that philosophers of history do not yet know how to answer: What roles do virtues in the sense of personal dispositions or character traits play in the acquisition of historical knowledge? To what extent can historians' evaluative standards - Noël Carroll's (1990) 'truth-tracking criteria' or Mark Bevir's (1999) 'criteria of comparison' - be formulated in terms of virtues (Nievergelt 2018)? How can historical studies be demarcated from other genres if their standards of virtue largely mirror the moral codes and social expectations of their culture? Do only individuals possess virtue or can groups or institutions also be bearers of virtue? If virtues are deeply ingrained habits, then to what extent can 'historian' still be considered a role-identity, distinct from other role-identities like 'citizen', 'spouse', and 'parent'? Or on a more conceptual level: How do virtues relate to skills, 
qualities, and competencies? Are these different words for the same type of dispositions or are there substantial differences between, say, virtues and skills? ${ }^{10}$ These are all questions that emerge out of historical research and are still awaiting philosophical treatment.

This brings us to a fourth and final argument in favor of HPH. In the hermeneutic space of $\mathrm{HPH}$, philosophers of history can familiarize themselves with the history of historical studies, not merely to acquire data for theory testing, but also to explore understudied aspects of historical studies. Keeping current with historiographical literature can help them avoid relying on stock examples of what historians do. Likewise, cooperation with historians of historical studies can provide them with fresh insight into the intricacies of historical studies. For philosophers of history, then, HPH may serve as a space of innovation: a space in which new ideas sometimes emerge.

\section{Four questions}

At this point, I can imagine readers to raise a couple of questions. Although few readers will be against cooperation as such, they might want to hear more about the aims and limits of such cooperation, perhaps especially at a time when talk of 'interdisciplinarity' runs a risk of becoming so clichéd as to lose any distinct meaning (Brown and Schubert 2007; Jacobs 2013: 1-3). I can imagine, therefore, that readers raise at least four questions: (1) If HPH aims to understand 'historical studies', does this phrase refer exclusively to academic historical studies? (2) Why should only historians and philosophers be invited to the table? (3) If 'understanding' historical studies is the aim, then who defines what understanding is? After all, depending on their theoretical leanings, historians and philosophers may well have different ideas of what understanding implies. (4) Is HPH something to be built from scratch? Or is it already among us, in one form or another? I will respond to these questions in turn.

(1) Is it necessary for HPH to limit itself to academic historical studies such as practiced in history departments or in other parts of the humanities ? $^{11}$ I have argued on other occasions that a focus on 'relations with the past' not only has the advantage of broadening philosophy of history's traditional epistemic scope, but also can cover more than only academic historical studies. All human beings, after all, in one way or another, maintain relations with the past (Paul 2015a). So if the second H in HPH can encompass people's relations with the past, cannot HPH also encompasses scholarship on nostalgia as a mode of dealing with loss (Becker 2018), 
historicization of racism in the American Black History Month (Van de Mierop 2016), or the 'practical past' in Hayden White's (2014) sense of the word?

Although, in principle, such a broad understanding of the second $\mathrm{H}$ in $\mathrm{HPH}$ can only be applauded, it might be strategically more beneficial to start with what most historians and philosophers of history have in common: an interest in academic historical studies. Given that philosophers of history are still largely unfamiliar with the cultural-historical prisms through which historians have begun to examine historical studies, shared explorations of how academics read, think, teach, write, and tweet about the past may already yield a lot of new insight. Also, even though an expansion of philosophy of history beyond 'philosophy of historiography' would be very welcome, this would not necessarily be a move from which historians of historiography can profit, given that they increasingly cooperate with historians of science and historians of the humanities more than with historians of historical culture. So if the analogy with HPS assigns priority to historians and philosophers reflecting together on what professional historical studies are, it does so on pragmatic, strategic grounds - not because it would be less pertinent to study how non-academics relate to their pasts.

(2) Something similar applies to the second question: If the challenge is to deepen our understanding of historical studies, then why are history and philosophy the only disciplines that are invited to the table? Given that HPH is largely modelled after the example of HPS, it would not be far-fetched to think that HPH might include historical equivalents of sociologists examining laboratory cultures or anthropologists studying the working habits of high energy physicists. ${ }^{12}$ Such an 'anthropology of historians' even seems to be in the making, judging by recent work by Van Troi Tan and Patrick-Michel Noël (2018). This is exciting, if only because anthropological fieldwork might teach historians and philosophers of history alike that academics writing books and debating historical interpretations are always situated subjects, busy grading student papers and preparing PowerPoints for their next class while having a Skype conversation with colleagues abroad about a potential collaborative grant application and writing a letter of recommendation for a recent graduate who tries to enter the academic job market. ${ }^{13}$ Still, given that historians and philosophers of history have a more established tradition of analyzing historical studies, they are likely to be most interested in contributing to the project called $\mathrm{HPH}$.

(3) What exactly does 'understanding' historical studies mean? As Richard Mason (2003) and others have argued, different disciplines have different understandings of 
understanding. This has serious implications for any 'multi-' or 'interdisciplinary' project that tries to build bridges between fields. If historians assume that understanding has been reached when empirical descriptions are as complete as possible, while philosophers believe that understanding requires extraction of universal truths from historical contingencies, then historians telling philosophers what the aim of their cooperation is, or vice versa, amounts to an act of disciplinary imperialism that almost certainly discourages further attempts at cooperation.

Fortunately, however, this hermeneutic situation of a conversation between people committed to different views on the aim of the conversation is not peculiar to disciplinetranscending initiatives like HPH. Disagreement over the nature of understanding also exists within disciplines (De Regt 2017). As said, the Commission of the History of Historiography was founded in 1980 in response to historians who strongly disagreed about what historical understanding entailed - whether it would require patterns and regularities, as social science enthusiasts at the time believed, or take the form of stories, as narrative-oriented historians claimed (Erdmann 2005: 278-98). And as philosophers of history know well, even historians committed to story-telling might hold different views on what a story is or what kind of 'emplotment' is appropriate in historical writing (White 1973). This implies that divergence of views on what it means to understand historical studies should not be regarded as a special obstacle to $\mathrm{HPH}$. Divergence on ultimate aims is a common feature of hermeneutic practices even within monodisciplinary contexts.

Therefore, if I argue that historians and philosophers of history can help each other deepen their understanding of historical studies, this does not imply that, at the end of the day, historians and philosophers should be able to issue a joint declaration on realized learning objectives. I already quoted Scott Weingart (2015: 202) as saying that cooperation is successful as soon as 'interesting results' come out of it, irrespective of whether all parties involved agree on what makes an interesting result. The hermeneutic space called HPH is not a laboratory designed for executing well-delineated research projects, but an open space in which questions can be raised, ideas can be exchanged, and hypotheses can be tried out. The only demand that this space makes upon participants is that they are, and remain, committed to dialogical virtues (curiosity, generosity, empathy, open-mindedness) without which no productive exchange can take place. 
(4) Finally, one may wonder: Is HPH a project that has to be started from scratch or does it already exist, in one form or another? As suggested by the examples of Dray, Donagan, Martin, Bunzl, Lorenz, and other scholars committed to bringing history and philosophy of history into conversation with each other, quite a bit of work at the intersection of philosophy of history and the history of historical studies has already been done. Wherever historians or philosophers of history use philosophical concepts for understanding historical studies, test philosophical theories against historiographical evidence, hold up a philosophical mirror to 'working historians', or explore historiographical literature in the hope of developing new philosophical ideas, something like HPH takes place. Cross-fertilization between historical and philosophical perspectives is also the explicit aim of workshops of the kind organized by the International Commission for the History and Theory of Historiography (ICHTH).

Last but not least, not unlike HPS, HPH exists in educational settings, most notably in 'historical theory' or 'historiography' courses offered to majors or graduate students in history. ${ }^{14}$ Given that history students do not usually have much philosophical baggage, not a few of these courses are so designed as to encourage students to test philosophies of history against evidence from their own historical practice. Instead of requiring students to engage in amateur philosophizing, this didactic format allows them to familiarize themselves with philosophical texts through confronting Carl G. Hempel, Arthur C. Danto, or Hayden White with their own niche of historical studies. ${ }^{15}$ For much the same reason, textbooks like Mark Day's The Philosophy of History (2008) and my own Key Issues in Historical Theory (2015) abound with historiographical examples aimed to illustrate, or challenge, philosophical theories about how historians interpret, explain, and narrate the past.

As these examples show, HPH is clearly not a project waiting to be realized. It is not an 'ground-breaking' line of research or a teaching paradigm that requires historians and philosophers of history to abandon their current working habits. HPH is already among us, whether we call it by that name or not.

\section{Conclusion}

History and philosophy of history (HPH) as advocated in this chapter seeks to enrich historical and philosophical studies of historical scholarship by cultivating a hermeneutic space in which historians and philosophers of history can learn from each other. The idea of this hermeneutic space is not to let historians and philosophers work on pre-defined problems or force them 
into the straightjacket of a common line of research. Instead, HPH encourages historians to try out philosophical concepts, while inviting philosophers of history to test their theories against historiographical evidence. More interestingly, perhaps, HPH allows philosophers to stumble upon new ideas - there is a wealth of cultural-historical approaches to historical studies that has not yet been subjected to philosophical scrutiny - while encouraging historians to use philosophical tools in reflecting on their own practice.

By invoking history and philosophy of science (HPS), not as a model for imitation, but by way of instructive analogy, the HPH label suggest that historians and philosophers of history may interact as fruitfully as historians and philosophers of science sometimes manage to do. Just as the historians of science Lorraine Daston and Peter Galison (2006) make productive use of concepts borrowed from philosophers of science, while philosopher Guy Axtell (2016) in his turn tries to learn from Daston's and Galison's genealogies of scientific objectivity, so historians and philosophers of history may enrich each other's work.

Although this exchange is premised on the assumption that cross-fertilization between historical and philosophical insights is beneficial to understanding historical studies (academic historical studies in the first place), I have emphasized that historians and philosophers do not need to agree on what 'understanding' means to be able to profit from questions and concerns raised by scholars from other disciplinary backgrounds. Just as in real life, instructive exchanges between historians and philosophers can take place without participants agreeing on the aims of the conversation. The only thing that HPH asks from them is an unwavering commitment to dialogical virtues like curiosity, generosity, empathy, and open-mindedness.

Like HPS, then, $\mathrm{HPH}$ is not a marriage or some other kind of love relationship: Ronald Giere's metaphor has to be rejected as inapt. HPH more resembles a meeting room with a large round table, soft chairs, a coffee machine, and windows with outside views that can be opened to let in lots of fresh air. Initially, the round table conversation seems to benefit most from an invitation policy restricted to historians and philosophers of history. Given that they have an established tradition of studying historical studies, historians and philosophers seem currently best positioned to engage in HPH. Only time can tell whether sociologists and anthropologists interested in historical studies will at some point also be invited to the table.

\section{Acknowledgments}


Drafts of this chapter were presented to the Philosophy of History Seminar at the Institute of Historical Research in London (December 2017), at an ICHTH workshop, 'What Are Historians Doing: Practice and Pragmatics of History Writing', at Tallinn University (August 2018), and to the Philosophy of History Study Group at the University of Amsterdam (September 2018). It's my pleasure to thank Kalle Pihlainen, Marek Tamm, and Rik Peters for their kind invitations and the audiences at all three occasions for their perceptive feedback. Also, I would like to thank the editor of this volume, Jouni-Matti Kuukkanen, for his thoughtful engagement with the theme of this chapter in a lengthy video interview, recorded at the Center for Philosophical Studies of History at Oulu University (October 2019) and available on YouTube: https://t.co/CCiXLyfyQg. Funding was generously provided by the Netherlands Organization for Scientific Research (NWO).

\section{Bibliography}

Ankersmit, F. R. (2001), Historical Representation, Stanford: Stanford University Press.

Ankersmit, F. R. (2015), Sublime Historical Experience, Stanford: Stanford University Press.

Ankersmit, F. R. et al. (2007), 'The Philosophy of History: An Agenda', Journal of the Philosophy of History, 1: 1-9.

Arabatzis, T. and J. Schickore (2012), 'Ways of Integrating History and Philosophy of Science', Perspectives on Science, 20 (2012), 395-408

Axtell, G. (2016), Objectivity, Cambridge: Polity Press.

Becker, T. (2018), 'The Meanings of Nostalgia: Genealogy and Critique', History and Theory, 57: 234-50.

Bevir, M. (1999), The Logic of the History of Ideas, Cambridge: Cambridge University Press. Bevir, M. and H. Paul (2012), 'Naturalized Epistemology and/as Historicism: A Brief Introduction', Journal of the Philosophy of History, 6: 299-303.

Brown, T. and A. Schubert (2007), 'The Growth of Research on Inter- and Multidisciplinarity in Science and Social Science Papers, 1975-2006', Scientometrics, 73: 345-51.

Bunzl, M. (1997), Real History: Reflections on Historical Practice, London: Routledge.

Burian, R. M. (1977), 'More than a Marriage of Convenience: On the Inextricability of History and Philosophy of Science', Philosophy of Science, 44: 1-42.

Carroll, N. (1990), 'Interpretation, History, and Narrative', The Monist, 73: 134-66. 
Clark, J. F. M. (2015), 'Intellectual History and History of Science', in R. Whatmore and B. Young (eds), A Companion to Intellectual History, 155-69, Chichester: Wiley-Blackwell.

Creyghton, C. (2016), 'La survivance de Michelet: historiographie et politique en France depuis 1870', PhD thesis University of Amsterdam.

Daston, L. (1995), 'The Moral Economy of Science', Osiris, 10: 2-24.

Daston, L. and P. Galison (2007), Objectivity, New York: Zone Books.

Daston, L. and H. O. Sibum (2003), 'Introduction: Scientific Personae and Their Histories', Science in Context, 16: 1-8.

Davis, N. Z. (1978), 'Women on Top: Symbolic Sexual Inversion and Political Disorder in Early Modern Europe', in B. A. Babcock (ed), The Reversible World: Symbolic Inversion in Art and Society, 147-90, Ithaca, NY: Cornell University Press.

Day, M. (2008a), 'Our Relations with the Past', Philosophia, 36: 417-27.

Day, M. (2008b), The Philosophy of History: An Introduction, London: Continuum.

De Regt, H. W. (2017), Understanding Scientific Understanding, Oxford: Oxford University Press.

Domski, M. and M. Dickson (2010), 'Introduction: Discourse on a New Method, or a Manifesto for a Synthetic Approach to History and Philosophy of Science', in M. Domski and M. Dickson (eds), Discourse on a New Method: Reinvigorating the Marriage of History and Philosophy of Science, 1-20, Chicago: Open Court.

Donagan, A. (1969), 'Alternative Historical Explanations and Their Verification', The Monist, 53: 58-89.

Donagan, A. (1970), 'Can Philosophers Learn from Historians?' in H. E. Kiefer and M. K. Munitz (eds), Mind, Science, and History, 234-50, Albany, NY: State University of New York Press.

Donovan, A., L. Laudan, and R. Laudan (1992), 'Introduction to the Johns Hopkins Edition', in A. Donovan, L. Laudan, and R. Laudan (eds), Scrutinizing Science: Empirical Studies of Scientific Change, 2nd. ed., xi-xxiv, Baltimore, MD: Johns Hopkins University Press. Dray, W. H. (1964), Philosophy of History, Englewood Cliffs, NJ: Prentice-Hall.

Dray, W. H. (1978), 'Concepts of Causation in A. J. P. Taylor's Account of the Origins of the Second World War', History and Theory, 17: 149-74.

Dray, W. H. (1989), On History and Philosophy of History, Leiden: E. J. Brill. 
Dror, O. E. (2006), 'Fear and Loathing in the Laboratory and Clinic', in F. B. Alberti (ed.), Medicine, Emotion and Disease, 1700-1950, 125-43, Basingstoke: Palgrave Macmillan.

Dumouchel, P. (1991), 'Scrutinizing Science Scrutinized', Inquiry, 34: 457-73.

Erdmann, K. D. (2005), Toward a Global Community of Historians: The International Historical Congresses and the International Committee of Historical Sciences, 1898-2000, trans. A. Nothnagle, 278-98, New York: Berghahn.

Figal, G. (2010), Objectivity: The Hermeneutical and Philosophy, trans. T. D. George, Albany, NY: State University of New York Press.

Galison, P. (1997), Image and Logic: A Material Culture of Microphysics, Chicago: University of Chicago Press.

Galison, P. (2010), 'Trading with the Enemy', in M. E. Gorman (ed.), Trading Zones and Interactional Expertise: Creating New Kinds of Collaboration, 25-52, Cambridge, MA: MIT Press.

Gershoy, L. 'Some Problems of a Working Historian', in S. Hook (ed.), Philosophy and History: A Symposium, 59-75, New York: New York University Press.

Giere, R. N. (1973), 'History and Philosophy of Science: Intimate Relationship or Marriage of Convenience?', British Journal for the Philosophy of Science, 24: 282-97.

Giere, R. N. (2012), 'History and Philosophy of Science: Thirty-Five Years Later', in S. Mauskopf and T. Schmaltz (eds), Integrating History and Philosophy of Science: Problems and Prospects, 59-65, Dordrecht: Springer.

Gooday, G. (2006), 'History and Philosophy of Science at Leeds', Notes and Records of the Royal Society, 60: 183-92.

Gorman, J. (2008), Historical Judgement: The Limits of Historiographical Choice, Montreal: McGill-Queen's University Press.

Honkani, K. (2005), "'It Is Historically Constituted": Historicism in Feminist Constructivist Arguments', European Journal of Women's Studies, 12: 281-95.

Jacobs, J. A. (2013), In Defense of Disciplines: Interdisciplinarity and Specialization in the Research University, Chicago: University of Chicago Press.

Jenkins, K. (2003), Refiguring History: New Thoughts on an Old Discipline, London: Routledge. Kelley, M. J. and A. Rose, eds (2018), Theories of History: History Read across the Humanities, London: Bloomsbury, 2018. 
Knorr-Cetina, K. D. (1981), The Manufacture of Knowledge: An Essay on the Constructivist and Contextual Nature of Science, Oxford: Pergamon Press.

Kochan, J. (2013), 'Subjectivity and Emotion in Scientific Research', Studies in History and Philosophy of Science, 44: 354-62.

Krüger, L. (1979), 'History and Philosophy of Science: A Marriage for the Sake of Reason', in Abstracts: 6th International Congress of Logic, Methodology, and Philosophy of Science: Hannover, August 22-August 29, 1979: Section 6, 108-112, s.I.: s.n.

Kuhn, T. S. (1970), The Structure of Scientific Revolutions, 2nd ed., Chicago: University of Chicago Press.

Latour, B. and S. Woolgar (1979), Laboratory Life: The Social Construction of Scientific Facts, London: Sage.

Laudan, L. (1989), 'Thoughts on HPS: Twenty Years Later', Studies in the History and Philosophy of Science, 20: 9-13.

Laudan, L. et al. (1986), 'Scientific Change: Philosophical Models and Historical Research', Synthese, 69: 141-223.

Livingstone, D. N. (2003), Putting Science in its Place: Geographies of Scientific Knowledge, Chicago: University of Chicago Press.

Lorenz, C. (1994), 'Historical Knowledge and Historical Reality: A Plea for “Internal Realism”', History and Theory, 33: 297-327.

Martin, R. (1989), The Past Within Us: An Empirical Approach to Philosophy of History, Princeton: Princeton University Press.

Martin, R. (1997), 'The Essential Difference between History and Science', History and Theory, 36: 1-14.

Martin, R. (1998), 'Progress in Historical Studies', History and Theory, 37: 14-39.

Mason, R. (2003), Understanding Understanding, Albany, NY: State University of New York Press.

Matthews, M. R. (1994), Science Teaching: The Role of History and Philosophy of Science, New York: Routledge.

McAllister, J. W. (2018), 'Using History as Evidence in Philosophy of Science: A Methodological Critique', Journal of the Philosophy of History, 12: 239-58. 
McMullin, E. (1976), 'History and Philosophy of Science: A Marriage of Convenience?' in R. S. Cohen et al. (eds), PSA 1974: Proceedings of the 1974 Biannual Meeting Philosophy of Science Association, 585-601, Dordrecht: D. Reidel.

Müller, P. (2019), Geschichte machen: Historisches Forschen und die Politik der Archive, Göttingen: Wallstein.

Nayler, S. (2005), 'Introduction: Historical Geographies of Science: Places, Contexts, Cartographies', British Journal for the History of Science, 38: 1-12.

Nievergelt, O. (2018), ‘Die Idee geschichtswissenschaftlicher Objektivität: Eine tugendepistemologische Erkundung', PhD thesis ETH Zürich.

Otto, A. (1998), Het ruisen van de tijd: over de theoretische geschiedenis van Jan Romein, Amsterdam: Stichting Beheer IISG.

Paul, H. (2011), 'Performing History: How Historical Scholarship is Shaped by Epistemic Virtues', History and Theory, 50: 1-19.

Paul, H. (2012), 'Weak Historicism: On Hierarchies of Intellectual Virtues and Goods', Journal of the Philosophy of History, 6: 369-88.

Paul, H. (2015a), 'Relations to the Past: A Research Agenda for Historical Theorists', Rethinking History, 19: 450-8.

Paul, H. (2015b), Key Issues in Historical Theory, New York: Routledge.

Paul, H. (2017), 'Weber, Wöhler, and Waitz: Virtue Language in Late Nineteenth-Century Physics, Chemistry, and History', in J. van Dongen and H. Paul (eds), Epistemic Virtues in the Sciences and the Humanities, 91-107, Cham: Springer.

Pinnick, C. and George Gale (2000), 'Philosophy of Science and History of Science: A Troubling Interaction', Journal for General Philosophy of Science, 31: 109-25.

Porciani, I. (2009) 'Janus-Faced Clio: Gender in the Historical Profession in Europe', in C. Salvaterra and B. Waaldijk (eds), Paths to Gender: European Historical Perspectives on Women and Men, 11-30, Pisa: Pisa University Press.

Riesch, H. (2014), 'Philosophy, History and Sociology of Science: Interdisciplinary Relations and Complex Social Identities', Studies in History and Philosophy of Science, 48: 30-37.

Rubinoff, L. (1991), 'Introduction: W. H. Dray and the Critique of Historical Thinking', in W. J. van der Dussen and L. Rubinoff (eds), Objectivity, Method and Point of View: Essays in the Philosophy of History, 1-11, Leiden: E. J. Brill. 
Saxer, D. (2013), Die Schärfung des Quellenblicks: Forschungspraktiken in der Geschichtswissenschaft 1840-1914, Munich: Oldenbourg, 2013.

Schickore, J. (2011), 'More Thoughts on HPS: Another 20 Years Later', Perspectives on Science, 19: 453-81.

Schickore, J. (2018), 'Explication Work for Science and Philosophy', Journal of the Philosophy of History, 12: 191-211.

Schnicke, F. (2015), Die männliche Disziplin: Zur Vergeschlechtlichung der deutschen Geschichtswissenschaft 1780-1900, Göttingen: Wallstein.

Scholl, R. and T. Räz (2016), 'Towards a Methodology for Integrated History and Philosophy of Science', in T. Sauer and R. Scholl (eds), The Philosophy of Historical Case Studies, 6991, Cham: Springer.

Smith, B. G. (1998), The Gender of History: Men, Women, and Historical Practice, Cambridge, MA: Harvard University Press.

Stadler, F., ed. (2017), Integrated History and Philosophy of Science: Problems, Perspectives, and Case Studies, Cham: Springer.

Tollebeek, J. (2008), Frederica \& Zonen: een antropologie van de moderne geschiedwetenschap, Amsterdam: Bert Bakker.

Tollebeek, J. (2015), 'Commemorative Practices in the Humanities around 1900', Advances in Historical Studies, 4: 216-31.

Tran, V. T. and P. M. Noël (2018), 'For an Anthropology of Historians', Ethnologies, 40: 49-73.

Traweek, S. (1988), Beamtimes and Lifetimes: The World of High Energy Physicists, Cambridge, MA: Harvard University Press.

Trüper, H. (2014), Topography of a Method: François Louis Ganshof and the Writing of History, Tübingen: Mohr Siebeck.

Tucker, A. (2004), Our Knowledge of the Past: A Philosophy of Historiography, Cambridge: Cambridge University Press.

Van De Mierop, K. (2016), 'On the Advantage and Disadvantage of Black History Month for Life: The Creation of the Post-Racial Era', History and Theory, 55: 3-24.

Van der Meiden, G. W. (1982), 'Tranen bij de vaderlandse geschiedenis', in D. E. H. de Boer (ed.), Leidse facetten: tien studies over Leidse geschiedenis, 129-32, Zwolle: Waanders. Weingart, S. B. (2015), 'Finding the History and Philosophy of Science', Erkenntnis, 80: 20113. 
White, H. (1973), Metahistory: The Historical Imagination in Nineteenth-Century Europe, Baltimore, MD: Johns Hopkins University Press.

White, H. (2014), The Practical Past, Evanston, IL: Northwestern University Press.

White, P. (2009), 'Darwin's Emotions: The Scientific Self and the Sentiment of Objectivity', Isis, 100: 811-26.

Wimmer, M. (2012), Archivkörper: Eine Geschichte historischer Einbildungskraft, Konstanz: Konstanz University Press.

Zammito, J. H. (2004), A Nice Derangement of Epistemes: Post-Positivism in the Study of Science from Quine to Latour, Chicago: University of Chicago Press.

\section{Biographical note}

Herman Paul is Professor of the History of the Humanities at Leiden University. The author of Key Issues in Historical Theory (2015) and Hayden White: The Historical Imagination (2011), he is currently completing a book-length study of virtues and vices in nineteenth-century historical studies.

\footnotetext{
${ }^{1}$ In 1995, the commission was renamed the International Commission for the History and Theory of Historiography.

${ }^{2}$ On Giere's choice of metaphor, see also Giere 2012: 59 n. 1.

${ }^{3}$ Those others include Mark Day, whose analysis of historians' standards of evaluation such as expressed in book reviews appears in Day 2008: 21-4.

${ }^{4}$ VPI refers to Virginia Polytechnic Institute, where Larry and Rachel Laudan, among others, carried out the 'Testing Theories of Scientific Change' project described in Laudan et al. 1986.

${ }^{5}$ That is, for professional self-reflection of the kind illustrated by Gershoy 1963.

${ }^{6}$ On Dray's insistence that philosophers of history should reflect on what historians actually do, see also Rubinoff 1991.

${ }^{7}$ The metaphor of relations with the past is borrowed from Day 2008a.

${ }^{8}$ On the 'cultural turn' in the history of science, see Clark 2015.

${ }^{9}$ As happens, for instance, in Kochan 2013.

10 I offer some tentative reflection on these issues in Paul 2011, 2012.
} 
${ }^{11}$ For those 'other parts of the humanities', see the interesting explorations in Kelley and Rose 2018.

12 Classic studies are, of course, Latour and Woolgar 1979; Knorr-Cetina 1981; Traweek 1988.

${ }^{13}$ Although feminist philosophy of science has long insisted on the real-life situatedness of the knowing subject, feminist philosophy of history is still in statu nascendi. See only Honkani 2005.

${ }^{14}$ On the perceived educational promises of HPS, see Matthews 1994.

${ }^{15}$ In my experience at Leiden University, where I teach a research master's course on historical theory, this format greatly helps turning students' initial skepticism about philosophical reflection ('Why do we have to read this stuff?') into creative energy ('Let's see whether these guys understand what we are doing!'). 